\title{
食品微生物の増殖・代謝への通電処理・ 超音波照射の影響
}

微生物を取り巻く環境を検討しょうとすると, 物理的な条件としては温度, 圧力あるいは擋拌混合などの 限られたものになる。食品加工分野では, ジュール熱などの材料自体の発熱を利用する通電加熱の技術に関 心が集まっており，その際の条件（直流, 交流・周波数, 電圧, 連続またはパルスなど）によって、発熱に 限らず, 電気穿孔, 電気浸透などの現象の組合せ応用が始まっている。通電加熱ではその原理と温度制御が 容易であり, 容器等への放熱を低下させれば省エネ的でもある。精密な温度管理が求められる培養に適して いるように思えるが，実際にどのような効果が期待できるのであろうか。また，食品の分野では抽出・分散 の効果を利用される超音波は, 見かけ上は常温・常圧でありながら, 局所的には高温・高圧の環境を生み出 すことも知られている。では, 微弱なエネルギーレベルの超音波は微生物の培養時にどのような効果を示す のだろうか。こうした物理的条件での効果をいくつか紹介いただいた。

\section{野 口明 徳}

\section{1. はじめに}

微生物培養において温度管理は非常に重要である。 培地の多くを占める水の熱伝導率は $20^{\circ} \mathrm{C}$ で $0.504 \mathrm{kcal} /$ $\mathrm{m} \cdot \mathrm{h} \cdot{ }^{\circ} \mathrm{C}$ (因みに水は $-20^{\circ} \mathrm{C}$ で $2.05 \mathrm{kcal} / \mathrm{m} \cdot \mathrm{h} \cdot{ }^{\circ} \mathrm{C}$ ）で あり，それほど大きくはない。このため，外部熱源に よる温度管理では擋拌混合が必要になることが多く， 装置の形状サイズ・培地の性状によっては擋拌混合が 充分にできない問題に直面する。伝熱形式は伝導，伝 達，輻射に分けることができ，そのいずれも温度勾配 が熱移動の推進力であり, 温度勾配が大きいほど温度 上昇が進むが，熱交換面での品質劣化につながること から, 容器側の温度を高くすることは難しい。

食品加工の分野でも外部加熱では類似の問題が多発 しており，電子レンジなどでの対策を思いつきやすい。 しかし，マイクロ波での誘電損失が大きい水などが発 熱して素材の温度が上昇して扔り，発熱量が高いほど マイクロ波のエネルギーが減衰するため, 素材内部の 温度上昇は外表部の温度上昇による熱伝導に頼るのが 実態で，均一で迅速な加熱（温度上昇）は難しい。こ うした背景もあり, 材料自体が発熱する内部加熱方式
に関心が集まりつつあり，材料の導電性を利用したジ ユール熱に注目が特に集まっている。培地の成分は水 と各種電解質・栄養成分から構成されているために導 電性があり, 培地が均一であれば均一に電流が流れて ジュール熱を発生する。この場合, 電圧に応じて発熱 量を変えることが容易で, 温度制御も精密に行う事が できるので, 複雑な昇温プログラムも実施できる。容 器側への熱損失に注意すれば，省エネ的でもある。こ の手法を海外では, Ohmic Heating と呼んでおり, 国 内では通電により加熱することから通電加熱と呼ぶの が一般的である。通電では成分分離を避ける意味から も交流を利用するが，したがって，周波数を变化させ ると温度上昇あるいは微生物にどのような影響が生じ るかを検討することは非常に興味深いといえる。

温度均一のための擋拌混合は, 菌体と培地との境界 相をできるだけ小さくして物質交換を促進する効果も 生み出すと見ることができる。しかし，それは微生物 が動き得ない時に期待できる効果であり, 微生物と培 地が共に動く時は擋拌混合による物質交換促進の効果 は余り期待できない。これに対して, 音波としてのエ ネルギーがそれほど高くは無いが, 周波数が高い音波

Influence of low Intensity Ultrasound and Ohmic Heating on Growth and Metabolism of Microorganisms Akinori Noguchi (Ishikawa Prefectural University, Food Sciences) 
を照射して，場合によっては菌体が共振して動くよう な条件を得ることができれば，見かけ上の効率的な擋 拌混合となるはずである。したがって，様々な周波数 で微弱な超音波を培地に照射した場合, 菌の挙動にど のような変化が生じるかは興味深いものがある。実際, 超音波照射により活性化あるいは増殖促進などの研究 例は, 細菌 ${ }^{1-9)}$, 糸状菌 ${ }^{10-12)}$, 酵母 ${ }^{13-18)}$, 植物組織 ${ }^{19)}$ で報告されている。酵母では菌の増殖促進とそれに伴 う糖の消費増加およびエタノール生産の増加など, 興 味深い例が見出される。

美味しい酒，まろやかな酒を作るには，発酵現場で 音楽を流すと良い, 輸送時などの微弱な振動が効果的 である, 微弱な遠赤外線を照射すると良いなど, 様々 な情報があるが，いずれも科学的根拠がハッキリしな い経験的な現象と言えるだろう。

ここでは協会酵母（K-7）といくつかの乳酸菌を対 象に通電処理および超音波照射を行ったところ, 興味 深い結果を得たので紹介したい。

\section{2. 通電処理}

参考に通電処理で生じる現象を第 1 表にまとめてみ た。高電圧をパルス状で印加すると衝撃波あるいは電 気穿孔と呼ばれる現象が発生する。さて, 温度調節の ための熱量は弱い電圧で充分に得られる。第 1 図に示 す装置と条件で酵母を培養したところ，第 $2 \sim 4$ 図に 示す結果が得られた。培地の温度調節は非常に容易で

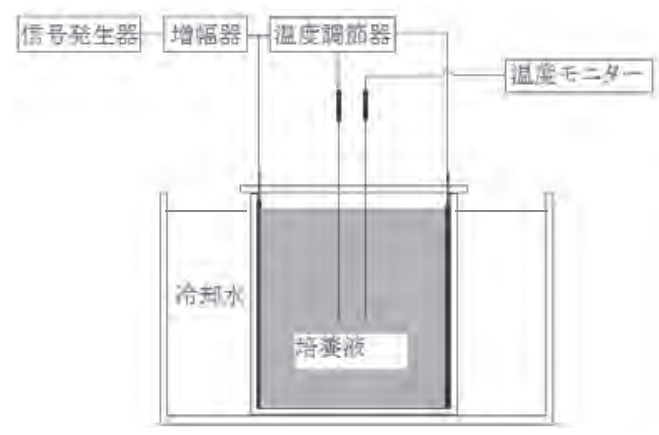

第 1 図 通電処理槽

電極はチタン製, シール型熱電対使用, 温度調節器で 通電 $\mathrm{ON} / \mathrm{OFF}$ により培養液温度を $30^{\circ} \mathrm{C}$ に保持。冷却 水温度調節で, 電力消費を変化。

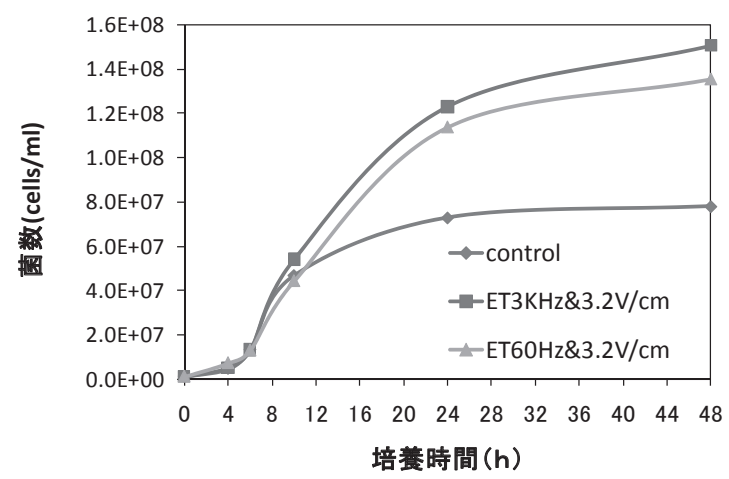

第 2 図 異なる周波数での通電温度制御と酵母増殖 Control は通電無し $\left(30^{\circ} \mathrm{C}\right.$ ), $\mathrm{ET}$ は通電温度制御(周波 数\&印加電圧)

第 1 表 通電処理で生じる現象

\begin{tabular}{|c|c|c|}
\hline & 普遍的な変化 & 菌懸濁液に特異的な変化 \\
\hline 1. 電界効果 & $\begin{array}{l}\text { 電気泳動 } \\
\text { 電界配向 } \\
\text { 電界解離 }\end{array}$ & $\begin{array}{l}\text { 電界誘導膜電位 } \Delta \phi=1.5 \mathrm{acos} \theta \\
\text { 膜内成分は } 1.5 \mathrm{a} / \mathrm{d} \text { 倍に増強した普遍的変化を受ける } \\
\text { 膜の電界圧縮 } \\
\text { 膜厚間大電流の発生 }\end{array}$ \\
\hline $\begin{array}{l}\text { 2. 熱的効果 } \\
\Delta \mathrm{T}=\mathrm{i}^{2} \mathrm{r} \Delta \mathrm{t} / \rho \mathrm{C}_{\mathrm{p}}\end{array}$ & $\begin{array}{l}\text { 化学平衡の } \\
\text { シフト } \\
\frac{\Delta \mathrm{K}}{\mathrm{K}}=\frac{\Delta \mathrm{H}}{\mathrm{RT}^{2}} \Delta \mathrm{T} \\
\text { 液媒圧縮 } \\
\text { (衝撃波) } \\
\Delta \mathrm{P}=\frac{\alpha}{\kappa} \Delta \mathrm{T}\end{array}$ & $\begin{array}{l}\text { 膜厚間温度勾配による締め付け効果 } \Delta \pi=\mathrm{cR} \Delta \mathrm{T} \\
\text { 熱浸透圧 } \Delta \mathrm{P}=-\frac{\mathrm{Q}}{\mathrm{vT}} \Delta \mathrm{T} \text { 効果 }\end{array}$ \\
\hline
\end{tabular}

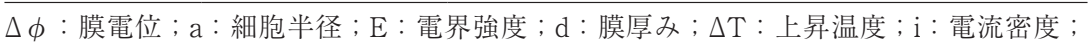
$r$ : 懸濁液の比抵抗; $\Delta t$ : 電界負荷時間 ; $\rho$ : 懸濁液密度 $; K$ : 化学平衡定数; $\Delta \mathrm{K}$ : 化学 平衡定数変化; $\Delta \mathrm{H}$ : 反応熱 ; $\mathrm{R}$ : 気体定数; $\Delta \mathrm{P}$ : 溶媒膨張による圧上昇 ; $\alpha$ : 懸濁液の膨 張係数; $\kappa$ : 懸濁液の圧縮率 $; \Delta \pi$ : 浸透圧差 $; C$ : 溶質濃度 $; \mathrm{Q}$ ：膜厚方向への溶媒熱の 流入； $\mathrm{v}$ ：液媒分子容 
かつ安定的に行えている。菌増殖では外部加熱による 温度調節に比べて, 通電加熱では明らかに菌数が多く, 特に対数増殖期前期で増殖促進が認められる。また, グルコース消費，エタノール生産も増加している（第 4 図)。これらの結果は, 菌数増加と比べると, 単位 菌体の活性化では無く, 増殖促進が主原因と思われる。 高い周波数での通電では菌体の細胞膜の絶縁を乗り越 えて菌体内に電流が流れると予想できることから，第 2 図に示すように周波数を $60 \mathrm{~Hz}$ から $3 \mathrm{kHz}$ に換えて みたが, 効果がやや強められる程度で大きな差は観察 されなかった。また，第 3 図に示すように消費電力の 影響については優位な差が認められない。

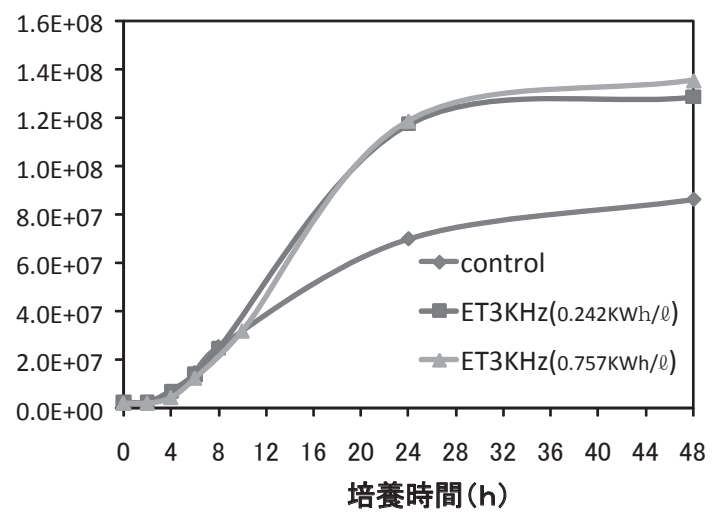

第 3 図 同一周波数 $(3 \mathrm{kHz})$ で異なる電力消費時の酵 母増殖

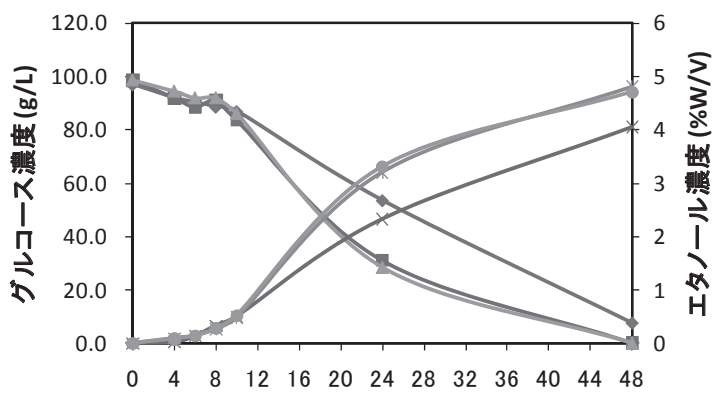

培養時間 (h)

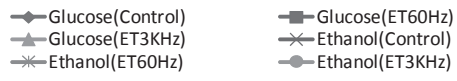

第 4 図 培養液成分の変化

異なる周波数での培養時の培地組成変化。

通電時ではグルコース消費とエタノール生成が促進さ れる。
以上の結果は通電加熱が狙いでもあり連続通電の条 件であったが, 通電自体の影響を明確にするために, バースト正弦波低電圧を培養液に印加し, 協会酵母 k-7 および耐塩性酵母（Zygosaccharomyces rouxii) の増殖への影響を検討した。バースト正弦波とは特定 周波数の交流をパルス的に印加することを意味し，検 討した条件は, 印加電圧：1 V/cm（協会酵母）， 0.25 $\mathrm{V} / \mathrm{cm}$ (耐塩性酵母) ; 波形 : sine ; 周波数 : $0.01 \sim 1$ $\mathrm{MHz}$; 発振モード： burst；パルス幅：0.1 s ; パルス 間隔： $0.4 \mathrm{~s}$ である。その結果, 温度変化の少ないバ ースト正弦波低電圧を培養液に印加することにより, コントールに比べて協会酵母の増殖が速くなり（第 5 図), グルコースの消費速度やエタノールの生成量が 大きいことが分かった。周波数が高いほど, その効果 が大きくなる傾向が見られた。また, 耐塩性酵母につ いては,より高い効果があることが判明した（第 6 図）。

以上は温度調節のためで比較的低い電圧で十分であ るが, 高電圧の印加についてどのような影響が生じる かを検討した。この場合の高電圧パルスは直流であり， 印加時期は増殖対数期前期の培養開始 8 時間目で, 第 7 図に示すように菌の増殖が促進された。また, この 時間以前でのパルス印加でも類似の効果が観察され, 一方, 対数期中期以降では効果はほとんど観察されな い。いずれの場合もこの印加電圧での死滅が観察され ないので, 電気穿孔などの膜損傷が生じている可能性 は低い。ただし，菌の形態は約 10\% ほどの膨潤が観

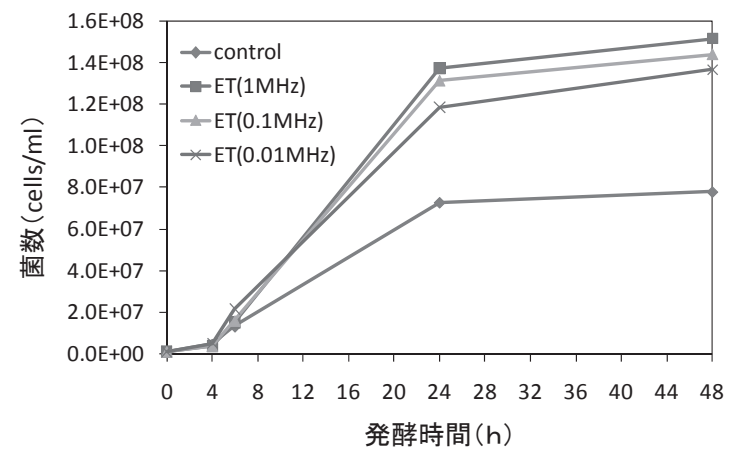

第 5 図 バースト正弦波低電界による清酒酵母増殖 への影響

菌株：清酒酵母 K-7 (Saccharomyces cerevisiae)

培地：YM10, $30^{\circ} \mathrm{C}$ バース卜正弦波低電界条件：印 加電圧 : $1 \mathrm{~V} / \mathrm{cm}$, 波形 : sine 周波数 : $0.01 \sim 1 \mathrm{MHz}$ パルス幅：0.1S パルス間隔：0.4S 


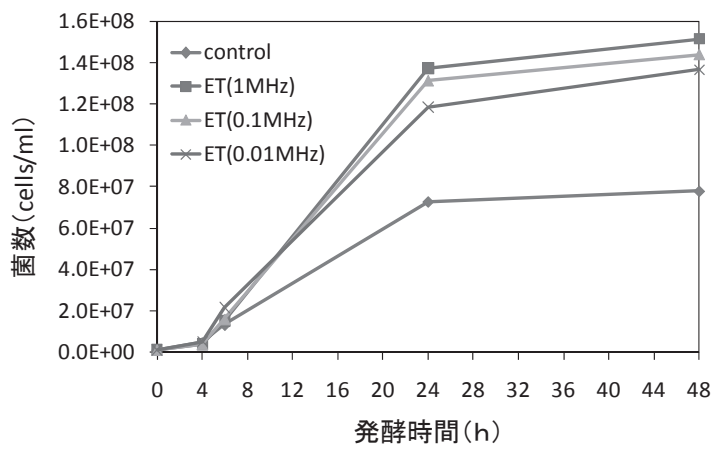

第 6 図 バースト正弦波低電界による耐塩性酵母増 殖への影響

菌株: 而塩性酵母(Zygosaccharomyces rouxii), 培地: YPG10, 培養液温度 : $30^{\circ} \mathrm{C}$, Water bath 温度 : $30^{\circ} \mathrm{C}$, バース卜正弦波低電界条件：印加電圧：0.25V/cm 波形: sine, 周波数: $0.1 \sim 1 \mathrm{MHz}$, パルス幅: $0.1 \mathrm{~S}$ パルス間隔： $0.4 \mathrm{~S}$

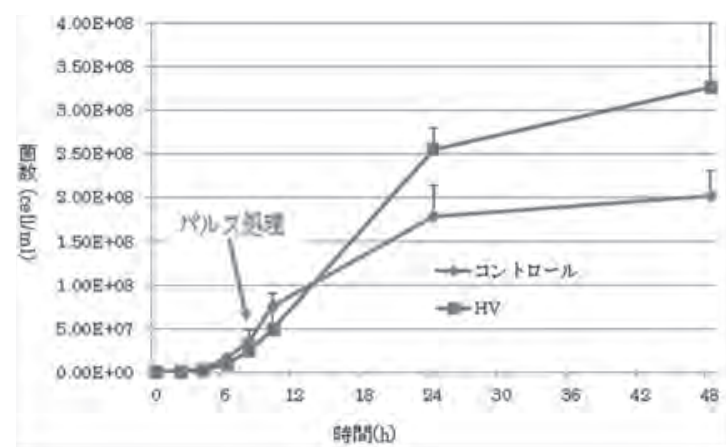

第 7 図高電圧パルス処理した酵母の増殖変化 培養温度 $30^{\circ} \mathrm{C}$, 印加電圧 $1200 \mathrm{~V} / \mathrm{cm}$ ，パルス巾 $100 \mu \mathrm{s}$, パルス回数 99 回, パルス間隔 $200 \mathrm{~ms}$

察され，さらに遺伝子発現では数多くの遺伝子郡が活 性化もしくは抑制されていた。その詳細は現在, 検討 中である。

以上の様に通電処理は温度調節以外に菌の増殖など に影響を与えることが明らかで，今後の研究進展が期 待される。

\section{3. 超音波照射}

「はじめに」の項で述べたように, 高い周波数の超 音波を微弱なレベルで培地に照射した場合，微生物の 生育・代謝にどのような影響を与えるのであろうか。 超音波の発信素子は二枚の電極に挟まれた結晶のピエ
ゾ効果を利用しており，発生する超音波の周波数をあ る範囲で変えることができる。素子への印加電圧の増 減で音波の強度（振幅）を強弱することができる。

培養槽（第 8 図）を用い, 培地温度は外部循環の温 水で調節した。発信素子から出た超音波は培養槽を取 り囲む温度調節用の水を介して培養槽のポリエチレン フィルムを貼った空から槽内培地を通り抜けて反対側 の空から出る仕組みになっている。通り抜けた超音波 が反射波として入らないようにするために温水循環槽 に傾斜板が設けてある。協会酵母 K-7 では第 9 図に示 すように $2.4 \mathrm{MHz}$ 固定で $6 \mathrm{~V}$ 以上の音波強度で増殖 促進効果が得られ, さらに $6 \mathrm{~V}$ 以上では印加電圧（出 力）の違いによる効果の差は見られない。印加電圧を $24 \mathrm{~V}$ 固定とし, 周波数を変化させると, $2.4 \mathrm{MHz}$ に 比べて $0.3 \mathrm{MHz}$ 拉よび $0.6 \mathrm{MHz}$ でより増殖の促進効 果が観察できた（第 10 図）。

音の進行波の伝搬速度 $\mathrm{v}$ 、周波数 $\mathrm{f}$, 波長入とすると $\mathrm{v}=\mathrm{f} \cdot \lambda$ となる。この速度 $\mathrm{v}$ は, 液体の体積圧縮率 $\mathrm{K}$,

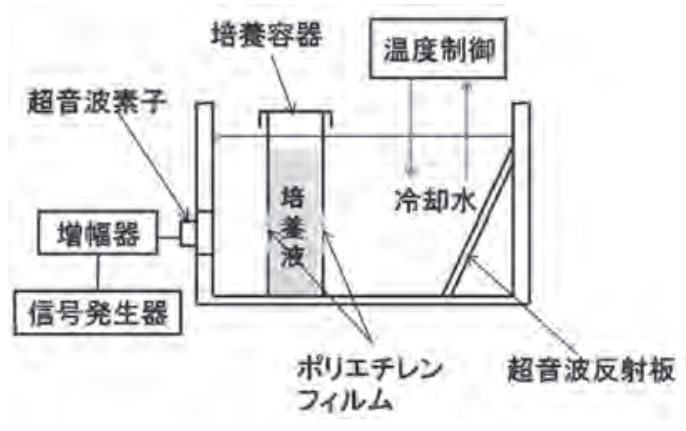

第 8 図 超音波培養槽

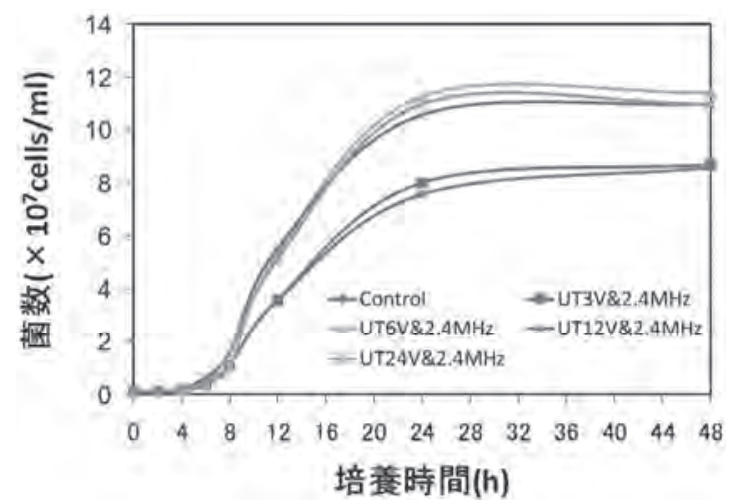

第 9 図 超音波照射による酵母 $\mathrm{k}-7$ への影響 


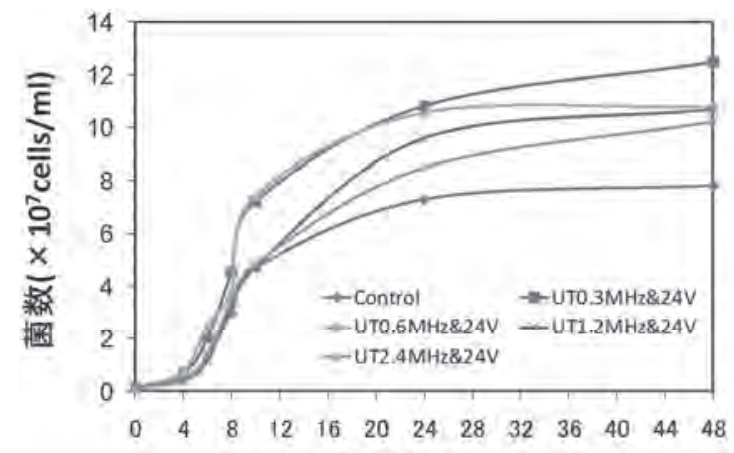

培養時間( $(\mathrm{h})$

第 10 図酵母 K-7 の増殖に及ぼす超音波周波数の影響

密度 $\rho$ の時に $\mathrm{v}=(\mathrm{K} / \rho)^{1 / 2}$ となる。水中での音速を $1500 \mathrm{~m} / \mathrm{s}$ とすれば, $2.4 \mathrm{MHz}$ の時は前式より, 1500 $\times 10^{3} \times 10^{3}(\mu \mathrm{m})=2.4 \times 10^{3} \times 10^{3} \times \lambda(\mu \mathrm{m})$ となって,$\lambda$ $=625(\mu \mathrm{m})$ の值から, 酵母の長径 $5-10 \mu \mathrm{m}$ の 60 倍 以上となり，照射した超音波によって酵母が共振する とは考えにくい。0.3 MHz, $0.6 \mathrm{MHz}$ でも同様である。
検討した協会酵母 K-7 の懸濁液に蛍光剤カルセイ ン (calcein) ${ }^{20)}$ を加え, 集菌洗浄して蛍光強度を測定 すると，ほとんど蛍光が観察されない（第 11 図）。す なわちカルセインは酵母内部に入っていないと思われ る。しかし, 培養時と同じ条件の $2.4 \mathrm{MHz}, 24 \mathrm{~V}$ で 超音波照射を行うと菌体から蛍光が観察される。また 細胞膜非透過性であり, 菌の死滅後に菌体内に入って 核と結合して赤色蛍光を発するとされる PIを加えた 場合, 超音波照射の有無に関係なく, 酵母の蛍光は観 察されなかった。これらの事実は, 検討した超音波照 射条件では酵母は損傷していないこと, 酵母の膜の透 過性が超音波照射時に増加したことを強く示唆してい る。

超音波による酵母増殖への促進効果が観察されたが, 耐塩性酵母 (Zygosaccharomyces rouxii) の場合は YPD $10 \%(\mathrm{NaCl} 10 \%)$ の培地で抑制効果が観察さ れた。また, 超音波照射強度や照射量を減少すること で，その影響を低減できること，グルコース $10 \%$ の 培地において, $2.4 \mathrm{MHz}, 24 \mathrm{~V}$, 連続照射ではグルコ
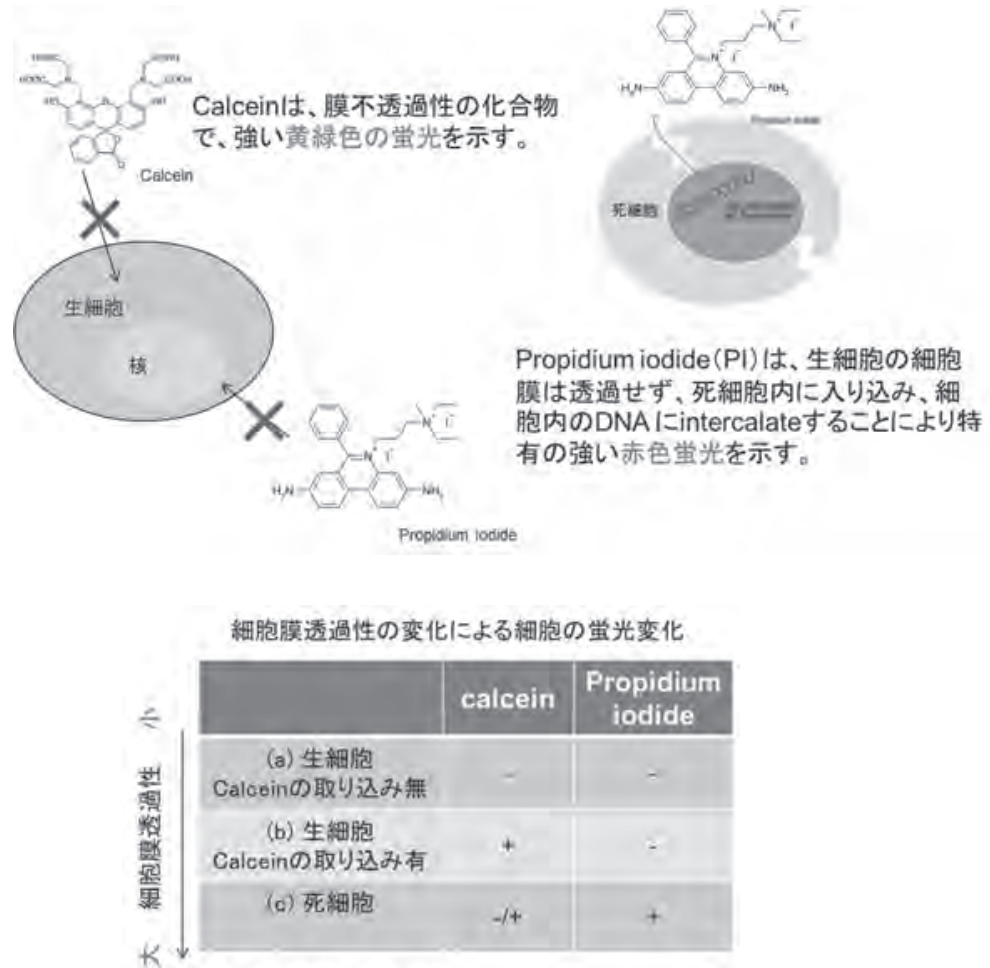

注: 辤光有 $(+)$, 単光無 $(-)$

第 11 図 蛍光剤: Calcein と Propidium iodide 
ースの消費抑制が観察されたことは興味深い。超音波 照射で膜透過性が変化して $\mathrm{NaCl}$ の酵母内への流入が 生じ, 阻害的に作用している可能性を示唆している。

乳酸菌でも興味深い超音波効果が観察されている。 研究内容は以下の通りである。米糖化液に乳酸菌（ $L$. plantarum: JCM1149, pickled cabbage 由来) を接 種し, 超音波の照射条件下もしくは非照射条件下で, 静置培養することで乳酸発酵を行い, 適宜培養液をサ ンプリングし，菌数，pH值を測定した。また， -20 ${ }^{\circ} \mathrm{C}$ にて凍結保存したものを香気成分の測定用試料とし, 凍結融解した試料を TCT 法でヘッドスペース成分を Tenax TA 管に捕集後, GC-MSにて測定した。

米糖化液を超音波連続照射条件下, $10^{\circ} \mathrm{C}$ で乳酸発酵 させたところ, 3-hydroxy-2-butanone：3HB や 2-met hyhl-1-propanol などの成分には大きな変動がなかっ たものの，米糖化液の不快臭を構成すると考えられる 3 種のアルデヒド (2-methyl-propanal : 2MP, 2-me thyl-butanal : 2MB, 3-methyl-butanal : 3MB) が特異 的に消失していることが確認された（第 12 図）。本現 象が超音波照射によるものか乳酸発酵によるものかを 確認するため, 乳酸菌無添加の米糖化液を同様の条件 下で超音波照射したところ，3 種のアルデヒドの低減 化は不完全であった。一方, 超音波無照射条件下, 30 ${ }^{\circ} \mathrm{C}$ で乳酸発酵したものについても 3 種のアルデヒドは 消失することが確認されたことから，超音波発酵時の 低臭化は, 超音波による脱気効果よりも菌体の増殖・ 代謝の促進による効果が大きいと考えられる。

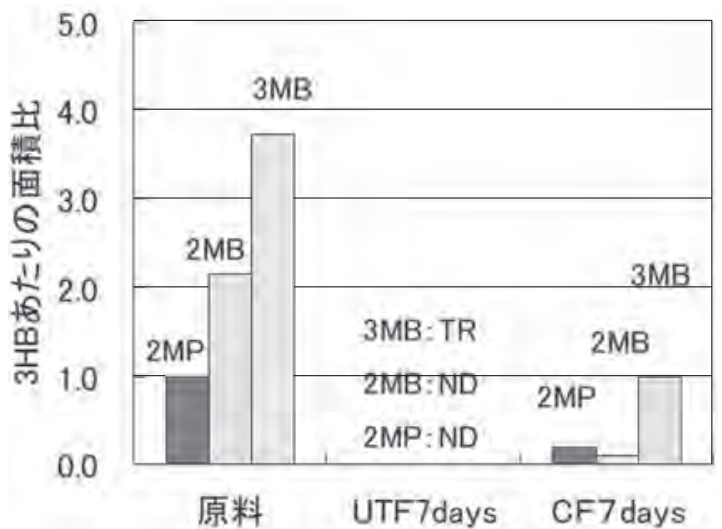

第 12 図超音波発酵の有無による香気成分の変化 (原料: 米糖化液, UTF7days : $2.4 \mathrm{MHz}, 24 \mathrm{~V}, 10^{\circ} \mathrm{C}$, 7 日間発酵, CF7days: $10^{\circ} \mathrm{C}, 7$ 日間発酵)
乳酸菌への超音波効果を検討した他の研究例を紹介 する。対象はヤギ乳でその乳酸発酵である。ヤギ乳は 牛乳に比べて, 脂肪球が小さいため消化吸収がよく, 乳糖が少ないため下痢になりにくいなどの長所がある。 また， $\alpha$ ガインを含まず，約 75 \%の確率でアレル ギーが発生しないと報告されている。しかし一方で, ヤギ乳は乳糖の含量が低いため発酵速度が遅く, 腐敗 のチャンスも多いことから，これまで発䣲原料として のヤギ乳の選択性を狭められてきた。そこで, 乳酸菌 の中でアンジオテンシン変換酵素 (angiotensin converting enzyme：ACE）阻害成分生産に優れた菌株 を選抜し、ヤギ乳発酵試験を行っている。北陸地域の 発酵食品由来の乳酸菌で ACE 阻害成分生産に優れた L. plantarum C 株を選抜し, MRS 培地で前培養を行 ったのち, 滅菌したヤギ乳に投入し, $30{ }^{\circ} \mathrm{C} て ゙$ 発酵を 行い, ヤギ乳の固化・pHの低下等をモニターした。 対照として M 社の市販製品をヤギ乳にそのまま投入 する実験区を設けた。また, 発酵中の超音波照射は, 第 8 図に示した超音波発酵槽を用い, 周波数は 2.4 $\mathrm{MHz}$, 波形はSine, 発振モードは Continuous, 印加 電圧は $24 \mathrm{~V}$ にて行った。

対照およびL. plantarum C 株の両方において超音 波照射区に $\mathrm{pH}$ 低下速度の向上がみられた（第 13 図）。 また，L. plantarum C 株を用いて作製した超音波照 射発酵乳において, 非照射に比して苦味アミノ酸群の 濃度低下やうまみアミノ酸の濃度増加が観察された。 また，第 14 図に示すように，超音波照射により，発 酵ヤギ乳の ACE 阻害活性が増加する傾向が見られた。

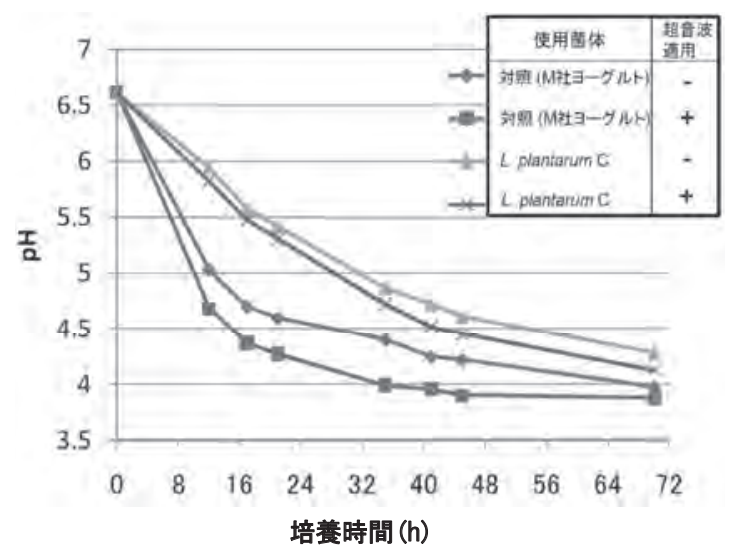

第 13 図 ヤギ乳乳酸発酵時の $\mathrm{pH}$ 変化 


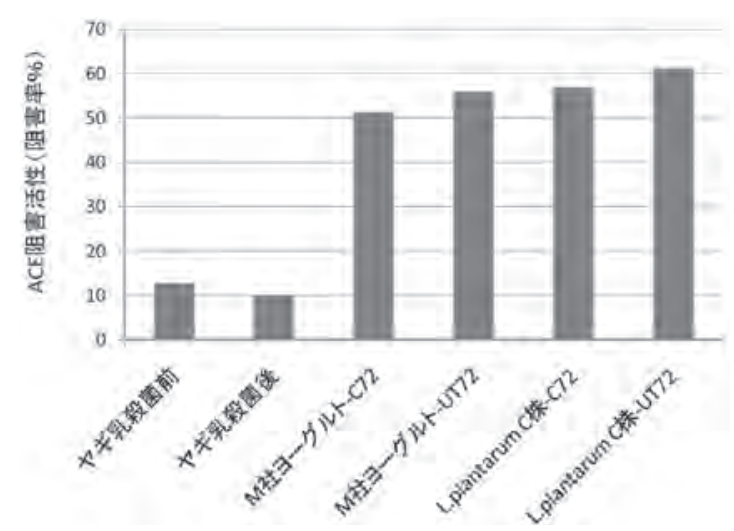

第 14 図 ACE 阻害活性成分生成に及ぼす超音波の 影響

これらの結果は，その機構が未だハッキリしていな いが微生物培養あるいは発酵の分野で物理的な処理が 新たな展開を引き起こす可能性を示しており, 当該分 野のより一層の研究展開を期待している。

〈石川県立大学 食品科学科〉

\section{参考文献}

1) R. Bar, Biotechnology and Bioengineering 32, 655-663 (1988)

2) M. Zabaneh, R. Bar, Biotechnology and Bioengineering 37, 998-1003 (1991)

3) J. Chu, B. Li, S. Zhang, Y. Li, Process Biochemistry 35,569-572 (2000)

4) C.M. Runyan, J.C. Carmen, B.L. Beckstead, J.L. Nelson, R.A. Robinson, W.G. Pitt, Journal of General and Applied Microbiology 52, 295-301 (2006)

5) M. Sakakibara, D. Wang, K. Ikeda, K. Suzuki, Ultrasonics Sonochemistry1, S107-S110 (1994)

6) D. Wang, M. Sakakibara, Ultrasonics Sonochemistry 4, 255-261 (1997)

7) B.E. Wood, H.C. Aldrich, L.O. Ingram, Biotechnology Progress 13, 232-237 (1997)
8) H. Wu, G.J. Hulbert, J.R. Mount, Innovative Food Science and Emerging Technologies 1, 211-218 (2000)

9) E. Joyce, S.S. Phull, J.P. Lorimer, T.J. Mason, Ultrasonics Sonochemistry10, 315-318 (2003)

10) D. Chuanyun, W. Bochu, D. Chuanren, A. Sakanishi, Colloids andSurfaces B: Biointerfaces 30,37-41 (2003)

11) D. Chuanyun, W. Bochu, Z. Huan, H. Conglin, D. Chuanren, L. Wangqian, Y. Toyama, A. Sakanishi, Colloids and SurfacesB: Biointerfaces 34, 7-11 (2004)

12) N.S. Herran, J.L.C. Lopez, J.A.S. Perez, Y. Chisti, Journal of Chemical Technology and Biotechnology 83, 593-600 (2008)

13) J.M. Anderson, Biochimica et Biophysica Acta 11, 122-137 (1953)

14) K. Matsuura, M. Hirotsune, Y. Nunokawa, M. Satoh, K. Honda, Journal of Fermentation and Bioengineering 77, 36-40 (1994)

15) S. Lanchun, W. Bochu, L. Zhiming, D. Chuanren, D. Chuanyun, A. Sakanishi, Colloids and Surfaces B: Biointerfaces 30, 43-49 (2003)

16) C. Jomdecha, P. Prateepasen, in: Proceedings of the 12th Asia-Pacific Conferenceon Nondestructive Testing, 5-10 November, Auckland, New Zealand, 2006.

17) A.Z. Sulaiman, A. Ajit, R.M. Ynus, Y. Chisti, Biochemical Engineering Journal, 54, 141-150 (2011)

18) H. Hu, Y. Yonezawa, A. Matsuda, N. Ishida, A. Noguchi, Food Sci.Tech. Res., 18, 611-616 (2012)

19) H. Böhm, P. Anthony, M.R. Davey, L.G. Briarty, J.B. Power, K.C. Lowe, E. Benes, M. Gröschl, Ultrasonics 38, 629-632 (2000)

20) J. D. Hutcheson: Thesis Quantification and control of ultrasound-mediated cell death modes. Georgia Institute of Technology (2008) 